\title{
Multidisciplinary consensus statement on the clinical management of patients with stage III non-small cell lung cancer
}

\author{
M. Majem ${ }^{1}$ (1) J. Hernández-Hernández ${ }^{2} \cdot$ F. Hernando-Trancho ${ }^{3} \cdot$ N. Rodríguez de Dios ${ }^{4} \cdot$ A. Sotoca $^{5}$. \\ J. C. Trujillo-Reyes ${ }^{1} \cdot$ I. Vollmer ${ }^{6} \cdot$ R. Delgado-Bolton ${ }^{7} \cdot$ M. Provencio $^{8}$
}

Received: 26 March 2019 / Accepted: 11 May 2019 / Published online: 6 June 2019

(c) The Author(s) 2019

\begin{abstract}
Stage III non-small cell lung cancer (NSCLC) is a very heterogeneous disease that encompasses patients with resected, potentially resectable and unresectable tumours. To improve the prognostic capacity of the TNM classification, it has been agreed to divide stage III into sub-stages IIIA, IIIB and IIIC that have very different 5-year survival rates (36, 26 and 13\%, respectively). Currently, it is considered that both staging and optimal treatment of stage III NSCLC requires the joint work of a multidisciplinary team of expert physicians within the tumour committee. To improve the care of patients with stage III NSCLC, different scientific societies involved in the diagnosis and treatment of this disease have agreed to issue a series of recommendations that can contribute to homogenise the management of this disease, and ultimately to improve patient care.
\end{abstract}

Keywords Lung cancer · Multimodal management $\cdot$ Staging $\cdot$ Multidisciplinary team $\cdot$ Induction therapy $\cdot$ Chemotherapy $\cdot$ Radiotherapy $\cdot$ Surgery

\section{Introduction}

In the 8th edition of the TNM classification proposed by the International Association for the Study of Lung Cancer (IASLC), accepted by the Union for International Cancer Control (UICC) and the American Joint Committee on Cancer (AJCC), stage III non-small cell lung cancer (NSCLC) encompasses patients who, in the absence of metastatic disease (M0), present N2 or N3 disease, a tumour with T4 characteristics or one classified as T3 N1 [2] (Table 1). It is,

This is a collaborative project of: Mariano Provencio on behalf of Grupo Español de Cáncer de Pulmón (GECP); Florentino Hernando-Trancho on behalf of Sociedad Española de Cirugía Torácica (SECT); Roberto Delgado-Bolton on behalf of Sociedad Española de Medicina Nuclear e Imagen Molecular (SEMNIM); Margarita Majem on behalf of Sociedad Española de Oncología Médica (SEOM); Nuria Rodríguez de Dios and Amalia Sotoca on behalf of Sociedad Española de Oncología Radioterápica (SEOR); Jesús Hernández-Hernández and Juan Carlos TrujilloReyes on behalf of Sociedad Española de Neumología y Cirugía Torácica (SEPAR) and Ivan Vollmer on behalf of Sociedad Española de Radiología Médica (SERAM).

M. Majem

MMajem@santpau.cat

Extended author information available on the last page of the article therefore, a very heterogeneous definition, which includes patients with resected, potentially resectable and unresectable tumours.

To improve the prognostic capacity of the 8th edition of the TNM classification compared to the previous one, certain modifications have been carried out, focusing mainly on: (a) defining the T category that has been regrouped based on the tumour diameter, with $1-\mathrm{cm}$ increment in size between T1a, T1b, T1c, T2a and T2b; T3 for 5-7-cm tumours, and T4 for tumours larger than $7 \mathrm{~cm}$. A tumour is considered T2 when there is main bronchial involvement that does not reach the main carina or partial/total atelectasis/pneumonitis, and T4 when there is invasion of the diaphragm [1, 2]; and (b) dividing stage III into sub-stages IIIA, IIIB and IIIC, since survival rates between stages are significantly different, with 5 -year survival of 36, 26 and $13 \%$, respectively [2, 3].

Staging and treatment of stage III NSCLC requires multidisciplinary management by expert physicians, and evaluation by cancer committees is essential. Given the heterogeneity of stage III NSCLC, the scientific societies involved in this work (Grupo Español de Cáncer de Pulmón [GECP], Sociedad Española de Cirugía Torácica [SECT], Sociedad Española de Medicina Nuclear e Imagen Molecular [SEMNIM]; Sociedad Española de Oncología Médica [SEOM]; Sociedad Española de Oncología Radioterápica [SEOR]; 
Table 1 Stage IIIA in the 8th TNM classification of lung cancer

\begin{tabular}{ccc}
\hline T & N & M \\
\hline Stage IIIA & & \\
T1a & N2 & M0 \\
T1b & N2 & M0 \\
T1c & N2 & M0 \\
T2a & N2 & M0 \\
T2b & N2 & M0 \\
T3 & N1 & M0 \\
T4 & N0 & M0 \\
T4 & N1 & M0 \\
Stage IIIB & & \\
T1a & N3 & M0 \\
T1b & N3 & M0 \\
T1c & N3 & M0 \\
T2a & N3 & M0 \\
T2b & N3 & M0 \\
T3 & N2 & M0 \\
T4 & N2 & M0 \\
Stage IIIC & & \\
T3 & N3 & M0 \\
T4 & N3 & M0 \\
\hline See & & T, N
\end{tabular}

See the definition of the T, N and $\mathrm{M}$ descriptors in Goldstraw et al. [3]

Sociedad Española de Neumología y Cirugía Torácica [SEPAR] and Sociedad Española de Radiología Médica [SERAM]) have developed this consensus statement to homogenise its treatment and, ultimately, improve the care of patients with stage III NSCLC.

\section{Staging of stage III NSCLC}

\section{Non-invasive staging}

Correct clinical staging is essential to manage patients with lung cancer. The first steps in the study of a possible thoracic neoplasm are the clinical history and a chest X-ray [4]. Further examinations should then be carried out to determine the local and distant involvement of the neoplasm. Computed tomography (CT) with intravenous contrast is the preferred technique in the study of lung cancer [2,5], and it should include the entire thorax and upper abdomen. It is not necessary to cover a larger area of the abdomen, since it does not significantly increase the accuracy of staging [6]. Positron-emission tomography (PET) with the glucose analogue ${ }^{18} \mathrm{~F}$-FDG and especially, PET/CT with ${ }^{18} \mathrm{~F}$-FDG, have revolutionised the staging of lung cancer.

$\mathrm{T}$ staging by CT will be indicated by the size of the main tumour, and this is one of the prognostic factors [2]. However, the degree of invasion of the mediastinal structures or the chest wall modifies the value of the $\mathrm{T}$ descriptor, as it impacts prognosis [7]. CT allows assessing the invasion of mediastinal vascular structures, although other techniques such as ultrasound or magnetic resonance imaging (MRI) have better results than $\mathrm{CT}$ when assessing the infiltration of the parietal pleura and the chest wall $[1,8]$. In the preoperative assessment of Pancoast tumours, MRI plays a fundamental role, with better results than CT scans [9].

When assessing mediastinal lymph node involvement, PET/CT with ${ }^{18} \mathrm{~F}-\mathrm{FDG}$ also plays a key role, with better results than CT [10-14]. However, its sensitivity is diminished in lymph nodes that are smaller than $10 \mathrm{~mm}$ in its short axis [15].

Initially, the presence of metastasis will be ruled out by cytohistological confirmation of suspicious lesions and possible extrathoracic lymph nodes that can classify the tumour as N3. A fine-needle aspiration (FNA) or an ultrasoundguided core-needle biopsy (CNB) can also be used [16, 17].

The initial scans should include the organs with the greatest potential of lung cancer metastases. One of the major contributions of PET/CT with ${ }^{18} \mathrm{~F}-\mathrm{FDG}$ in the initial diagnosis of lung cancer is the detection of previously unknown metastases, with the consequent change in staging [18].

Brain MRI is indicated in patients with lung tumours who are going to be treated with curative intent, to screen for brain M1 [19]. Brain MRI is superior to CT [20] and to $\mathrm{PET} / \mathrm{CT}$ [21].

\section{Non-surgical intrathoracic invasive staging}

In the case of already diagnosed intrathoracic tumours, stage III (N2 or N3) will be established without requiring pathological confirmation when there is an extensive mediastinal infiltration (bulky disease) [22].

In central tumours or those with enlarged hilar and mediastinal lymph nodes, the tumoral nature of the lymph nodes should be confirmed. An endobronchial ultrasound (EBUS)guided puncture will be performed since the positive and negative predictive values (PPV and NPV, respectively) of $\mathrm{CT}$ or PET are insufficient. EBUS would provide access to enlarged paratracheal, posterior tracheal, subcarinal, hilar, interlobar and lobar lymph nodes; and/or an endoscopic ultrasound (EUS) with access to paratracheal, subcarinal, paraesophageal and pulmonary ligament lymph nodes. Both techniques have a sensitivity close to $90 \%$ and a specificity of $100 \%$ [17, 22-25]. However, if the result is negative, not assessable or not sufficiently reliable (NPV: $<90 \%$ ), staging must be completed with surgical techniques [24, 26, 27].

Peripheral thoracic tumours without nodal disease require mediastinal invasive staging if not subsolid and with a diameter greater than $3 \mathrm{~cm}$ [28], since in these cases the possibility of finding occult N2 nodes exceeds $10 \%$ [22-24, 28] (Fig. 1). 


\section{Invasive surgical staging}

Invasive surgical mediastinal staging should be performed when the result of non-surgical invasive techniques is negative or non-assessable. Despite the greater morbidity and mortality, these methods are the standard of excellence of mediastinal staging, having a higher NPV (Table 2).

\section{Transcervical mediastinoscopy}

In the transcervical mediastinoscopy, a biopsy should be performed at a minimum number of nodal stations (\#4R, \#4L and \#7), as well as at stations \#2R and \#2L if they can be identified. Complications are scarce, with most being mild, and mortality is practically non-existent [29].

\section{Extended cervical mediastinoscopy}

Extended cervical mediastinoscopy is performed through the same incision of conventional mediastinoscopy and allows exploring the paraaortic and aortopulmonary window (\#5 and \#6) in the tumours of the left upper lobe, which are not accessible through conventional mediastinoscopy.

\section{Left parasternal mediastinotomy}

In the left parasternal mediastinotomy, stations \#5 and \#6 are explored through a second incision in the second left parasternal intercostal space.

Clinical history, physical examination, laboratory tests,

Alterations in X-ray-CT, PET and brain MRI.

The existence of metastasis has been ruled out

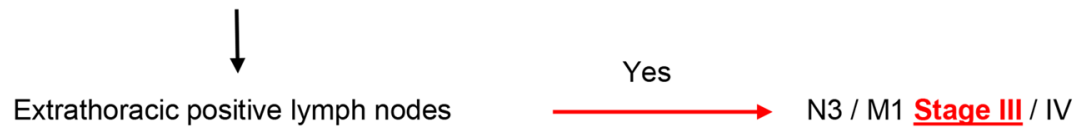

No

Intrathoracic lung cancer with or without lymphadenopathies

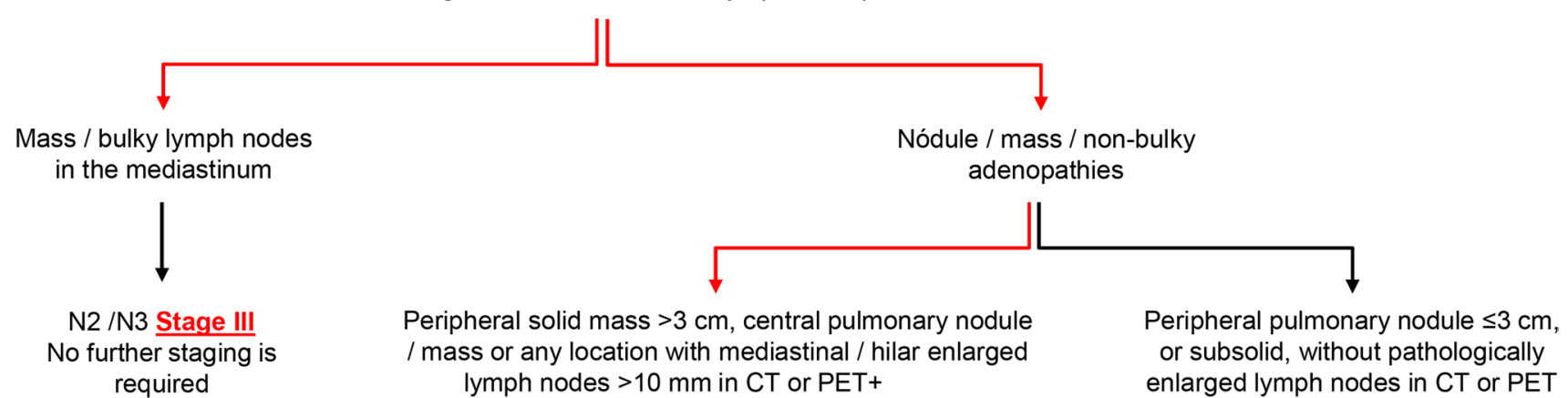
required

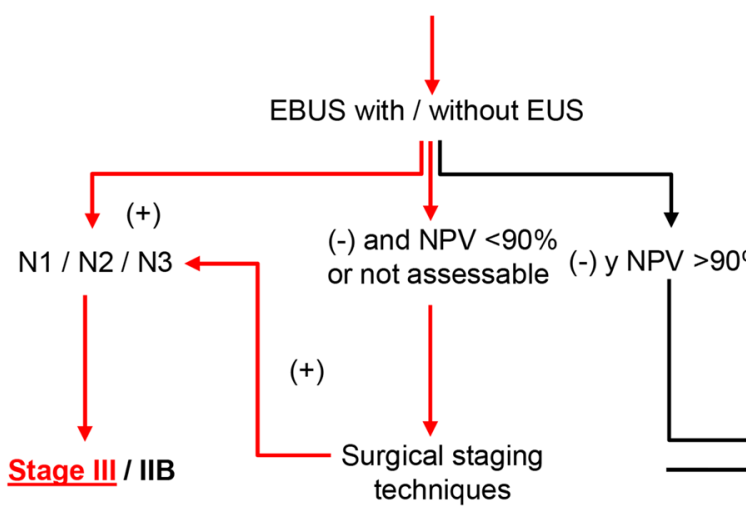
enlarged lymph nodes in CT or PET

Fig. 1 Performance algorithm for the staging of NSCLC* [17]. *The pathways leading to the diagnosis of stage III are highlighted in red. $C T$ computed tomography, NSCLC non-small cell lung cancer, EBUS endobronchial ultrasound, EUS endoscopic ultrasound, $P E T$ positron- emission tomography, PET/CT with ${ }^{18}$ F-FDG PET/CT with $18 \mathrm{~F}$ fluorodeoxyglucose, $N M R$ nuclear magnetic resonance, $X$-ray-CT $\mathrm{X}$-ray-computed tomography, $N P V$ negative predictive value 
Table 2 Main invasive surgical techniques for stage III NSCLC staging

\begin{tabular}{lrclll}
\hline Technique & Patients & Sensitivity (\%) & Specificity (\%) & NPV (\%) & PPV (\%) \\
\hline Transcervical mediastinoscopy [130] & 1362 & 86 & 100 & $>94$ & 100 \\
Extended cervical mediastinoscopy [131] & 221 & 67 & 100 & 94 & 100 \\
Left parasternal mediastinotomy [132] & 45 & 86 & 100 & 89 & 100 \\
Videothoracoscopy [133] & 55 & 100 & 100 & 100 & 100 \\
VAMLA [134] & 144 & 94 & 100 & - & 100 \\
TEMLA [135] & 698 & 96 & 100 & 99 & 100 \\
\hline
\end{tabular}

NSCLC Non-small cell lung cancer, TEMLA transcervical-extended mediastinal lymphadenectomy, $V A M L A$ video-assisted mediastinal lymphadenectomy, $N P V$ negative predictive value, $P P V$ positive predictive value

\section{Mediastinum pleuroscopy}

Mediastinum pleuroscopy is indicated when lymph node (N) and pleural (M) dissemination should be ruled out. Unlike all the other explorations, this technique should be performed with single-lung ventilation $[30,31]$.

\section{Videothoracoscopy}

The main advantage of videothoracoscopy is that it allows the exploration of the lower stations (\#8, \#9), but requires single-lung ventilation. It is also useful in the pre-operative staging of the $\mathrm{T}$ descriptor, as it can identify unresectable tumours that are not detected with imaging tests [32].

\section{Video-assisted mediastinal lymphadenectomy (VAMLA)}

The objective of VAMLA is the lymphadenectomy of those stations that can be accessed through mediastinoscopy (\#4R, \#4L, \#7, \#2R, \#2L).

\section{Transcervical-extended mediastinal lymphadenectomy (TEMLA)}

TEMLA provides the opportunity for a much wider lymphadenectomy to the lower stations except for station \#9. Morbidity and mortality are higher than in a conventional mediastinoscopy.

\section{Methods of restaging after induction}

\section{Imaging studies}

Although the usefulness of CT in restaging is uncertain, it has been observed that the response to neoadjuvant treatment by CT scan predicts a higher survival rate [33]. CT-based complete response has a high predictive value for complete pathological response, although it tends to underestimate it [34]. PET with ${ }^{18} \mathrm{~F}$-FDG offers good results when assessing the treatment response of the primary tumour and metastases, although it is less accurate in the assessment of the mediastinal response, with a false negative rate of $20 \%$ and a false positive rate of $25 \%$ [35]. As a prognostic factor, the degree of reduction of the standardized uptake value (SUV) in the primary tumour may be predictive of survival and of the pathological response to treatment [36-38].

\section{Cytohistological confirmation studies}

Re-evaluation usually starts with the same techniques used for initial staging.

\section{Non-invasive or minimally invasive techniques}

Bronchoscopy is reserved to confirm local tumour progression. Transbronchial needle aspiration (TBNA) achieves a correct diagnosis in $71 \%$ of patients and avoids other invasive procedures in $35 \%$ of cases [39]. The use of FNA by EBUS or EUS in restaging has a sensitivity lower than $80 \%$, with an NPV lower than this value [40-42]. Using both EBUS and EUS combined does not improve these results [43, 44]. When the results of EBUS and/or EUS do not show malignancy, it is recommended to use a surgical technique to reduce the proportion of false negatives $[26,45]$.

\section{Surgical techniques}

The first mediastinoscopy can be reserved for restaging when $\mathrm{N} 2$ is initially confirmed by TBNA, EBUS or EUS during the initial staging.

Re-mediastinoscopy is technically more complex. It shows a sensitivity higher than $60 \%$ (range $60-74 \%$ ), a specificity of $100 \%$, an accuracy greater than $80 \%$ (range $80-92 \%$ ), a PPV of $100 \%$ and a NPV of $73 \%$ (range $73-86 \%$ ) [46-48].

There are no restaging cases using VAMLA. As for TEMLA, authors present a restaging series with a sensitivity 
of $95 \%$, an NPV of $97 \%$, an accuracy of $98 \%$ and a specificity and PPV of $100 \%$ [49]. Finally, there is only one study that uses videothoracoscopy as a restaging method [50] with a sensitivity of $83 \%$, a NPV of $64 \%$ and a specificity of $100 \%$.

\section{Pre-treatment functional assessment}

\section{Pre-operative functional assessment}

Before surgery, it is necessary to check patient's heart function with patient's history and heart medication revision. It is also necessary to check if they have a thoracic revised cardiac risk index value that does not exceed 1.5 points [51]. The patient must be referred for a cardiology consultation if necessary.

To assess the risk derived from pulmonary resection, a pulmonary function study should be performed. This study should calculate the maximum expiratory volume in the first second of forced expiration (FEV1) and the diffusion capacity of the lung for carbon monoxide (DLCO) planned in the post-operative period (ppoFEV1 and ppoDLCO) [51-53]. When both indexes are greater than $60 \%$ of their theoretical values, the patient presents low risk and does not require further studies [51]. When the ppoFEV1 or the ppoDLCO is less than $30 \%$, a cardiopulmonary exercise testing (CPET) will be indicated to quantify maximum oxygen consumption $\left(\mathrm{VO}_{2 \mathrm{max}}\right.$ ). If this is lower than $10 \mathrm{~mL} / \mathrm{kg} / \mathrm{min}$ (or less than
$35 \%$ of its theoretical value), the surgical risk is high. If the value is between 10 and $20 \mathrm{~mL} / \mathrm{kg} / \mathrm{min}$ (between 35 and $75 \%$ of the theoretical value) the risk is intermediate, and if they are above the latter values the risk is low. When the ppoFEV1 or the ppoDLCO is less than $60 \%$ and both exceed $30 \%$, a CPET may be indicated, or stair climb/shuttle walk test may be used before CPET (Fig. 2) [51].

\section{Pre-radiotherapy functional assessment}

Although there are no clearly defined FEV1 or DLCO limits for radiotherapy, the same criteria of surgical case series are used in most chemotherapy/radiotherapy clinical trials. Both the dosimetric parameters, the mean lung dose (MLD) and the percentage of healthy lung volume that receives at least 20 Gy (V20) are effective tools to assess the risk of pulmonary toxicity, although some studies support the importance of the clinical characteristics of patients in the estimation of lung damage secondary to radiation [54].

\section{Multimodal management of stage III NSCLC}

\section{Incidental stage IIIA (N2)}

The need for adjuvant treatment has been evidenced by the poor results of local control and overall survival (OS) after surgery in patients with stage IIIA NSCLC. Several randomised clinical trials and meta-analyses have shown a
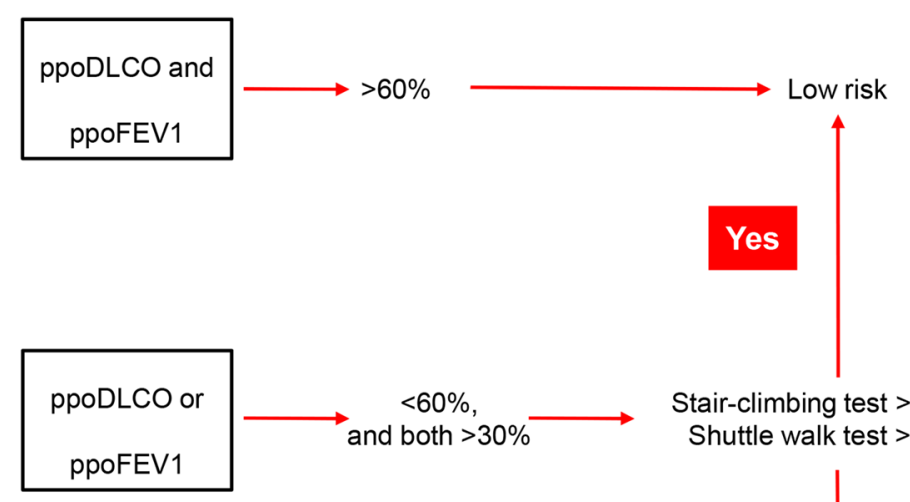

Stair-climbing test $>22 \mathrm{~m}$ or Shuttle walk test $>400 \mathrm{~m}$
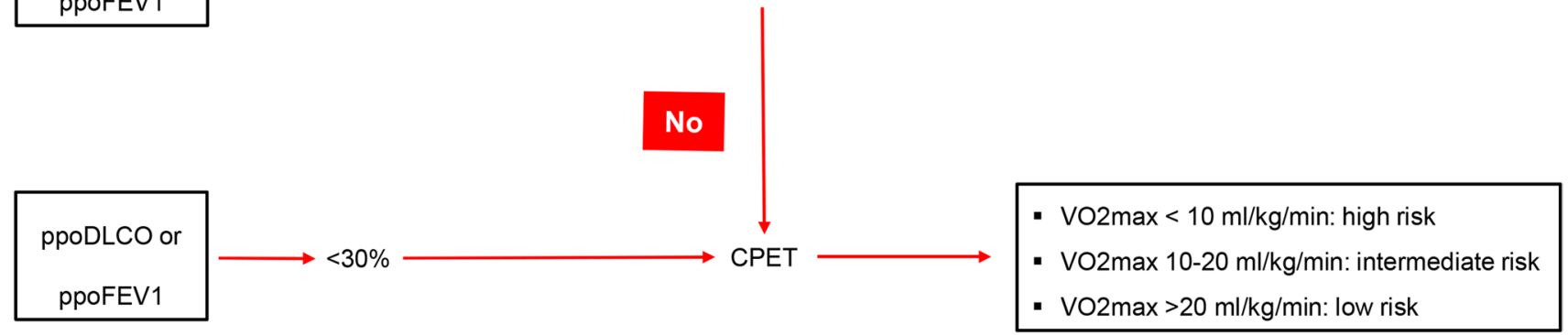

Fig. 2 Pre-operative functional assessment [51]. DLCO diffusing capacity of the lung for carbon monoxide, ppoDLCO planned postoperatively DLCO, FEVI forced expiratory volume in the first sec-

ond, ppoFEV1 planned post-operatively FEV1, CPET cardiopulmonary exercise test, $V O_{2 \max }$ maximum oxygen consumption 
5\% increase in OS at 5 years when administering adjuvant platinum-based chemotherapy $[55,56]$.

The role of post-operative radiotherapy (PORT) remains controversial. A first meta-analysis conducted in 1998 showed a relative increase in the risk of death $(21 \%)$, with a lower survival rate in patients receiving PORT [57]. However, a subsequent subgroup analysis established that this negative impact occurred in N0-N1 patients, although it was not clearly demonstrated in $\mathrm{N} 2$ patients. In several metaanalyses and subsequent retrospective studies, PORT in N2 patients reduced the risk of local relapse, without showing significant differences in OS [58-62]. However, since most of these studies were not performed with advanced radiotherapy techniques, the validity of their results could be questioned. It is, therefore, a priority to obtain information from randomised trials with modern techniques to establish its real impact on OS [63].

Regarding the sequence of treatments, it is recommended to administer sequential treatment starting with chemotherapy and to reserve concomitant treatment for patients with unresectable residual tumours, since adjuvant chemotherapy-radiotherapy has not shown an increase in OS and there was a greater toxicity.

\section{Potentially resectable stage IIIA (N2)}

The group of patients with stage IIIA N2 NSCLC is heterogeneous and their treatment should be discussed in a multidisciplinary committee. For this purpose, the individual characteristics of the patient, such as age, lung function, comorbidity and functional status, must be considered before and after the induction therapy (Fig. 3).

The main objectives of induction therapy are: (a) to eradicate subclinical metastases and mediastinal lymph node disease; (b) to improve local control of the disease; (c) to increase resectability; and (d) to reduce the magnitude of surgical resection.

The factors associated with a better prognosis in patients who undergo surgery are: confirmation of a complete response of the mediastinal (ypN0), achieving a complete resection and confirmation of a complete pathological response.

\section{Induction chemotherapy}

Several phase III studies have shown that platinum-based induction chemotherapy increases OS [64-71]. In stage IIIA (cN2) patients, induction chemotherapy increases OS compared to surgery alone $[67,69,72,73]$. These results have been confirmed in a subsequent meta-analysis [41].

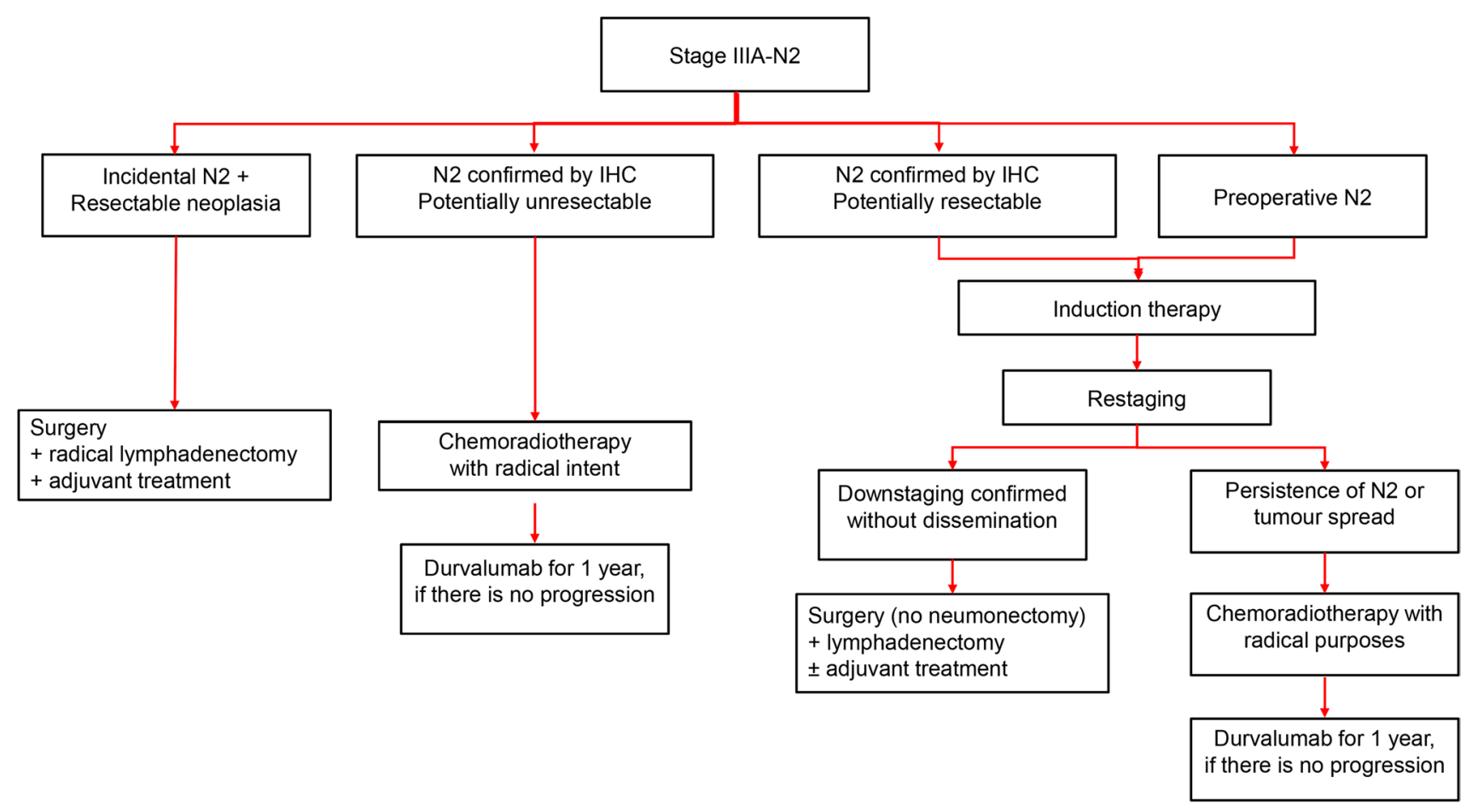

Fig. 3 Algorithm for the clinical management of patients with stage IIIA-N2 NSCLC. NSCLC Non-small cell lung cancer, IHC immunohistochemistry 


\section{Induction chemoradiotherapy}

The trials that analyse the role of treatment with induction chemoradiotherapy followed by surgery failed to show a survival benefit except in certain subgroups of patients [74-76]. A clinical trial randomised patients with resectable $\mathrm{N} 2$ disease (75\% a single station affected) to receive a concomitant chemoradiotherapy treatment (radiation dose of $45 \mathrm{~Gy}+$ cisplatin-etoposide) followed by surgery or radical radiotherapy (61 Gy). This trial showed a significant benefit in progression-free survival (PFS) in favour of trimodal treatment, without significant differences in OS [74]. The lack of benefit in the surgery arm may be a consequence of a higher early mortality, especially in patients who underwent a pneumonectomy. A study in patients with resectable stage III NSCLC showed a benefit for induction chemotherapy in terms of the pathological response, and also an improvement of the mediastinal stage, with no differences in survival rates [77].

A meta-analysis showed that the addition of radiotherapy to induction therapy does not increase survival [78], which raises questions about the need to add radiotherapy. It should be noted that several randomised studies have shown that mediastinal downstaging is associated with a better prognosis [79].

\section{Surgical treatment after induction}

Surgical resection after induction therapy is indicated when imaging tests rule out extrathoracic disease progression, functional assessment after induction therapy indicates that the patient can tolerate resection, restaging techniques confirm an improvement of the mediastinal status and the type of resection ensures a complete resection, but avoids a pneumonectomy $[74,75]$.

The goal of surgical treatment after induction therapy is to achieve surgery with complete resection (R0). The R0 criteria defined by the IASLC include: (a) tumour-free resection margins confirmed microscopically; (b) systematic mediastinal lymph node dissection; (c) no extracapsular invasion of affected nodes; and (d) the most distal node resected should be free of disease [80].

There is some consensus that a minimum of six lymph nodes from three $\mathrm{N} 2$ stations should be analysed (always including station 7) [81-83]. An adequate lymphadenectomy is considered a criterion for surgical quality $[84,85]$. Surgical resection is not recommended if R0 surgery is not feasible, radical radiotherapy could be administered if not previously done [86].

Based on the results obtained in patients who underwent surgery after induction therapy and still had mediastinal lymph node involvement (ypN2), surgery can be an option despite the persistence of $\mathrm{N} 2$ involvement in very specific cases, such as initial disease confined to a station that is not enlarged (resectable stage IIIA-N2), with PET/CT with ${ }^{18} \mathrm{~F}$ FDG results showing minimal residual disease, with resection less than a pneumonectomy, and when R0 is feasible.

\section{Adjuvant treatment with chemotherapy}

Although adjuvant chemotherapy improves disease-free survival in R0 patients [87], no specific data support adjuvant chemotherapy after induction therapy and surgery in initial stage IIIA-N2 NSCLC. Therefore, administration of adjuvant chemotherapy should be tailored for each patient, according to the pathological response and the pathology findings.

\section{Adjuvant treatment with radiation therapy}

Adjuvant radiotherapy therapy to the mediastinum is not recommended in $\mathrm{pN} 0$ or $\mathrm{pN} 1$ stage. When there is multiple hilar involvement, in extracapsular invasion or in $\mathrm{pN} 2$ stage, adjuvant radiotherapy may be considered if it has not been administered during induction therapy [88].

Administration of adjuvant radiotherapy to the $\mathrm{T}$ is not recommended in patients with surgery $\mathrm{R} 0$ and in the case of $\mathrm{R} 1$ or R2 surgery, adjuvant radiotherapy if not administered previously [88].

\section{Unresectable stages IIIA (N2), IIIB and IIIC}

Determination of unresectability in patients with stage III NSCLC must be determined by a multidisciplinary committee.

\section{Treatment with concomitant chemotherapy/radiotherapy}

Concomitant chemotherapy/radiotherapy is the treatment of choice for patients with a good general condition (ECOG $0-1)$ and a weight loss of less than 5\% in the previous 3 months [89]. This is a radical treatment that aims to cure the disease. A platinum-based chemotherapy regimen is recommended [90]. Gemcitabine regimens are not recommended because of higher pulmonary toxicity. The recommended radiotherapy dose is 60-66 Gy [91]. Concurrent chemoradiotherapy provides a median OS of 22-25 months and a 5 -year OS of $20 \%$ [92], with a grade 3 toxicity or higher consisting of oesophagitis (7-21\%) and pneumonitis (3-7\%) [93].

\section{Treatment with sequential chemoradiotherapy}

In patients with ECOG $>1$, weight loss greater than 5\% and a large volume to be irradiated with an unacceptable risk of 
pneumonitis, the recommendation is to administer induction chemotherapy followed by radical radiotherapy.

\section{Systemic treatment of stage III NSCLC}

\section{Adjuvant chemotherapy after stage IIIA (N2) incidental disease}

Patients with N2 disease documented during surgery are candidates for adjuvant chemotherapy (level of evidence: I, recommendation grade: A). The recommended regimen in patients without contraindications is cisplatin doublet chemotherapy, since it has shown to improve OS in complete resected patients. The recommended number of cycles is four (level of evidence: I, recommendation grade: A) [14]. Cisplatin-etoposide and cisplatin-vinorelbine are the platinum doublets with the greatest evidence, as shown in the LACE meta-analysis [56]. Carboplatin can be administered if there are contraindications for treatment with cisplatin.

\section{Induction chemotherapy}

Patients with potentially resectable IIIA-N2 disease can receive pre-operative treatment with chemotherapy, with or without radiotherapy, followed by surgery. The recommended induction chemotherapy regimen in patients without contraindications is to administer three to four cycles of a cisplatin doublet, based on complementary chemotherapy studies (level of evidence: II, recommendation grade: B).

Neoadjuvant chemotherapy has been shown to improve OS. In a meta-analysis of 15 randomised studies, a significant 5-year overall survival benefit of 5\% was observed in patients at stage IB-IIIA (HR: 0.87 ; 95\% CI 0.78-0.96; $p=0.007$ ) [73].

\section{Chemotherapy combined with radiotherapy}

In patients with unresectable stage III NSCLC, the administration of chemotherapy concomitant with radiotherapy is recommended (level of evidence: I, recommendation grade: A) [73]. In patients in whom concomitant treatment is not possible, the alternative is a sequential administration.

The recommended chemotherapy regimen is a cisplatin regimen with vinorelbine or etoposide [89, 94]. Most randomised studies comparing sequential versus concomitant treatment use cisplatin with etoposide or cisplatin with vinorelbine $[92,95]$. It is recommended to administer two to four cycles of chemotherapy concurrent with radiotherapy (level of evidence I, recommendation grade: A) [89].

Cisplatin can be replaced by carboplatin in patients with comorbidities that contraindicate treatment with cisplatin (carboplatin and paclitaxel is one of the most used regimens). In unresectable patients, cisplatin and pemetrexed regimens have not shown better results than standard treatment with cisplatin and etoposide concomitant with radiotherapy [96].

Age does not justify administering a suboptimal treatment in elderly patients. Therefore, the most convenient treatment should be administered according to the patient's illness and comorbidities (level of evidence: I, recommendation grade: A).

\section{Radiotherapeutic treatment of stage III NSCLC}

\section{Radiotherapy volumes}

Gross tumour volume (GTV) includes the primary tumour and the affected lymph nodes, when there is lymph node involvement. The clinical target volume (CTV) includes the GTV with a three-dimensional margin that incorporates the microscopic extension of the disease. The planning target volume (PTV) includes the CTV with a three-dimensional margin that considers the tumour movement and the uncertainties in the patient's daily positioning. Improving the immobilisation systems, respiratory movement control and image-guided radiation therapy (IGRT) can reduce the PTV margin [97].

Prophylactic irradiation of non-affected lymph node areas is not recommended, especially if PET/CT with ${ }^{18} \mathrm{~F}-\mathrm{FDG}$ has been performed during staging, since it does not increase survival and causes more toxicity $[98,99]$.

When post-operative radiotherapy is administered, the CTV should include the bronchial stump and the ipsilateral, subcarinal and contralateral hilar and paratracheal nodal areas $[60,100]$.

A correct definition of the healthy organs is a priority to minimise side effects, especially respiratory and cardiac [101, 102]. A useful source is the RTOG volume contouring atlas [103].

New technological advances such as 4D radiotherapy, the use of PET/CT with ${ }^{18}$ F-FDG for the simulation, intensitymodulated radiotherapy (IMRT) or volumetric-modulated arc therapy (VMAT), IGRT and the control of respiratory movement permit the administration of radical doses and reduce the impact on healthy organs, and should be used whenever available [104].

\section{Radiotherapy dose}

As part of a radical treatment, doses of 60-66 Gy at $2.0 \mathrm{~Gy} /$ day are recommended. Higher doses do not improve results and increase side effects [91]. In the case of sequential radiation therapy, accelerated radiotherapy schemes should 
be evaluated [105]. In post-operative irradiation, doses of 50-54 Gy at 1.8-2.0 Gy/day are usually indicated, although higher doses may be administered when there is extracapsular involvement or involvement of resection margins [60]. If radiation therapy is administered as part of an induction therapy, doses of 45-54 Gy at 1.8-2.0 Gy/day are usually used. A team of experienced thoracic surgeons is required when administering higher doses as induction therapy to avoid possible post-operative complications [106, 107].

\section{Surgical treatment of stage III NSCLC}

Surgery in patients with stage IIIA and IIIB non-N3 NSCLC should be considered in a multidisciplinary approach, especially if the R0 is feasible without pneumonectomy [19, 81 , $82,108-111]$. The best results are obtained after an adequate selection of the optimal therapeutic scheme and when the surgery is performed at hospitals that have trained surgical teams with anaesthesiology, thoracic surgery, nursing, rehabilitation, etc. [81-83, 108, 109, 111].

It is important to assess the resectability of the lesion and the operability of the patient. As mentioned previously, there are updated guidelines for this purpose in which predictable ppoFEV1 and ppoDLCO values and oxygen consumption have a central role in decision-making. There is not a single value or scale (Thoracoscore, ThRCRI, etc.) that indicates operability. The determination of the patient's general condition using the ECOG scale or the Karnofsky index as well as their expectations and socio-family environment will help to make individualised decisions regarding the surgical options $[112,113]$.

The standard anatomical resection is lobectomy or bilobectomy (level of evidence: I, recommendation grade: A). Anatomical segmental resection is considered in situations of impairment of the cardiopulmonary reserve. Pneumonectomy can be avoided, as far as possible, with bronchoplastic and angioplastic resections, since this procedure (especially if it is right pneumonectomy) has a significant impact on the results $[114,115]$.

The setting for the surgical approach would be the least invasive one, such as muscle-sparing thoracotomies, videoassisted thoracic surgery (VATS) or robot-assisted thoracic surgery (RATS). The purpose of this approach is to be the least aggressive possible and to manage these patients, who must necessarily receive neo- or coadjuvant treatments, safely. Anaesthetic and peri-operative care are crucial in the future for these patients [115]. In this context, there are multimodal rehabilitation protocols established, such as fasttrack or enhanced recovery after surgery (ERAS) [116].

\section{Consolidation treatment in unresectable stage III NSCLC}

Until recently, consolidation treatment with chemotherapy [92, 117], targeted therapy or some types of immunotherapy [118] failed to increase survival in patients with stage III NSCLC [119].

Recently, the administration of the anti-PD-L1 drug durvalumab as consolidation treatment for 1 year in patients with unresectable stage III NSCLC treated with radical chemoradiotherapy and with no progressive disease has been established as a new standard (level of evidence: I, recommendation grade: A). This is based on the results of a phase III clinical trial, in which durvalumab compared with placebo increased both the PFS (17.2 months vs. 5.6 months, respectively, $\mathrm{HR}, 0.51,95 \% \mathrm{CI} 0.41-0.63$ ) and the 2-year overall survival of $66.3 \%$ (95\% CI 61.7-70.4) with durvalumab to $55.6 \%$ (95\% CI 48.9-61.8) with placebo (HR, $0,68 ; 99.73 \%$ CI $0,47-0,997 ; p=0.0025)$. The benefit was consistent in all the pre-specified subgroups. Durvalumab was well tolerated, with a $15.4 \%$ of treatment discontinuation due to toxicity, and with grades 3-4 toxicity of $30.5 \%$ in patients treated with durvalumab and $26 \%$ of patients in the placebo group [120]. The European Medicines Agency (EMA) has approved durvalumab as a consolidation treatment in patients with locally advanced or unresectable NSCLC with expression of PD-L1 $\geq 1 \%$ of tumour cells and whose disease has not progressed after platinum-based chemoradiotherapy, based on an unplanned post hoc analysis of PD-L1 expression.

\section{Follow-up of patients with stage III NSCLC}

A key point in the follow-up of the patients diagnosed with a pulmonary neoplasm is quitting smoking, since this improves the prognosis of the disease [121]. Of note, it has been shown that a causal relationship may be inferred between smoking and increased mortality from any cause and mortality associated with cancer, as well as regarding the appearance of second lung neoplasms [121]. There is also a relationship, although it cannot be considered a cause, between smoking and an increased risk of recurrence, worse response to treatment and greater probability of suffering treatment-related toxicity [121].

The follow-up frequency of patients with lung cancer is controversial. SEOM and SERAM recommend that patients treated with surgery undergo follow-up with CT scan every 6-12 months during the first 2 years, and annually thereafter $[5,122]$. Some authors suggest that performing a PET/CT with ${ }^{18} \mathrm{~F}$-FDG 1 year after surgery is more sensitive than CT alone to detect recurrence [123]. 
Table 3 Recommendations for the clinical management of patients with stage III NSCLC

Non-invasive staging of stage III NSCLC:

$\mathrm{CT}$ scan of the thorax and upper abdomen with intravenous contrast is the preferred technique in the initial assessment when lung cancer is suspected

PET/CT with ${ }^{18}$ F-FDG is the most sensitive technique to explore mediastinal lymphadenopathy

Brain MRI is indicated in patients with lung neoplasm who are going to be treated with curative intent

\section{Invasive staging of stage III NSCLC:}

Non-surgical invasive staging methods are the first choice due to their lower associated morbidity and mortality.

In cases in which the result of invasive non-surgical techniques is negative or non-assessable, surgical staging methods should be recommended,

as they remain the standard of excellence in stage III NSCLC staging

Pre-treatment functional assessment:

Before conducting surgery on the patient, it is necessary to ensure that their cardiac function is adequate and to estimate the risk derived from pulmonary resection by means of a pulmonary function study

The FEV1 and the DLCO predicted after the scheduled surgery will be calculated

Functional assessment prior to radiotherapy is less defined, but the lung and heart doses should be minimised

\section{Multimodal management of stage III NSCLC}

Incidental Stage IIIA (N2):

In stage IIIA with incidental N2 involvement, the recommended treatment is surgical resection and adjuvant chemotherapy (level of evidence: I, recommendation grade: A)

The administration of sequential post-operative radiotherapy after completing chemotherapy has shown to increase local control of the disease, without being clear whether it provides an OS benefit (level of evidence: II, recommendation grade: C)

Potentially resectable stage IIIA (N2):

In potentially resectable stage IIIA-N2, initial surgical resection is not recommended (level of evidence: I, recommendation grade: A)

In potentially resectable stage IIIA-N2, the recommended treatment is induction chemotherapy, followed by surgery if there is improvement of the stage (level of evidence: I, recommendation grade: A), followed by adjuvant radiotherapy according to the findings after surgery (level of evidence: IV, recommendation grade: C)

Neoadjuvant chemotherapy/radiotherapy achieves a greater downstaging of mediastinal disease volume with respect to induction chemotherapy, without an impact on OS (level of evidence: I, recommendation grade: $\mathrm{C}$ )

Unresectable stages IIIA (N2); IIIB and IIIC:

In patients with ECOG 0-1, without weight loss $>5 \%$ and with irradiation volumes that do not compromise cardiopulmonary functionality, the administration of concomitant platinum-based chemotherapy/radiotherapy is recommended (level of evidence: I, recommendation grade: A), followed by consolidation treatment with durvalumab, if there is no disease progression

The administration of radiotherapy at doses higher than $66 \mathrm{~Gy}$ is not recommended (level of evidence: I, recommendation grade: A)

\section{Systemic treatment of stage III NSCLC}

The recommended chemotherapy regimens, either adjuvant, induction or radical combined with radiotherapy, are cisplatin doublets

\section{Radiotherapeutic treatment of stage III NSCLC:}

The recommended radiotherapy dose in radical chemoradiotherapy is 60-66 Gy at 2 Gy/day. If administered sequentially, accelerated schemes that reduce the total duration of treatment are recommended

In post-operative irradiation, doses of 50-54 Gy at 1.8-2.0 Gy/day are recommended. In case of extracapsular involvement or resection margins, higher doses may be administered

In case of induction radiotherapy, doses of 45-54 Gy are usually used

\section{Surgical treatment of stage III NSCLC:}

The standard anatomical resection is lobectomy or bilobectomy (level of evidence: I, recommendation grade: A).

Surgery in patients with stage III NSCLC is considered in a multidisciplinary and personalised treatment environment, especially if R0 is feasible without pneumonectomy

This surgery should be carried out at hospitals that have trained surgical teams

\section{Stage III NSCLC consolidation treatment:}

Durvalumab is recommended as consolidation treatment for 1 year in patients with unresectable stage III NSCLC with expression of PDL1 $\geq 1 \%$ in tumour cells and without progression after radical chemoradiotherapy (level of evidence: I, recommendation grade: A)

\section{Follow-up of patients with stage III NSCLC:}

Quitting smoking should be advised to patients undergoing treatment for lung cancer

It is recommended to carry out a CT scan every 6-12 months during the first 2 years and later annually

PET/CT with ${ }^{18} \mathrm{~F}-\mathrm{FDG}$ shows better results in the assessment of patients treated with chemoradiotherapy

The evaluation criteria for response to systemic treatments (RECIST, iRECIST) should be used according to the type of systemic therapy used

CT Computed tomography, DLCO diffusing capacity of the lung for carbon monoxide, EBUS endobronchial ultrasound, ECOG Eastern Cooperative Oncology Group, EUS endoscopic ultrasound, FEV1 forced expiratory volume in the first second, $M R I$ magnetic resonance imaging, $N S C L C$ non-small cell lung cancer, $P E T$ positron-emission tomography, PET/CT with ${ }^{18} \mathrm{~F}$-FDG, $O S$ overall survival, $R O$ complete resection 
In patients treated with radiotherapy or chemoradiotherapy, an initial PET/CT with ${ }^{18} \mathrm{~F}$-FDG and during follow-up is useful for predicting areas with greater potential for recurrence or treatment failure [124]. On the other hand, treatment response can be assessed early with a post-treatment PET/CT with ${ }^{18}$ F-FDG [125-127].

The response assessment criteria will be established based on the systemic treatment received. In most cases, the RECIST 1.1 criteria will apply [128], but for patients who have received immunotherapy, iRECIST criteria should be used [129]. In these patients, successive controls should be carried out in the event of tumour growths, given the possibility of pseudoprogression. However, to verify that these are true progressions and not peritumoural inflammatory reactions, controls should not be performed before 4 weeks after the last assessment.

\section{Conclusions}

Stage III NSCLC is a very heterogeneous disease in which multidisciplinary management is essential. A multimodal approach is necessary when establishing treatment for stage III NSCLC. This will depend on the stage III subtype (incidental, potentially resectable or unresectable), and may include surgery, chemotherapy and radiotherapy, as detailed in Table 3. Recently, consolidation therapy with durvalumab has become the new standard treatment for unresectable NSCLC after radical chemoradiotherapy and without disease progression.

Acknowledgements The authors are grateful for the editorial assistance of Beatriz Gil-Alberdi of HealthCo (Madrid, Spain) in the production of this manuscript.

Funding GECP, SECT, SEMNIM, SEOM, SEOR, SEPAR and SERAM are grateful for financial support for this project in the form of unrestricted grants from AstraZeneca.

\section{Compliance with ethical standards}

Conflict of interest M Majem reports personal fees from AstraZeneca, Roche, Eli Lilly, Bristol-Myers Squibb, Pfizer, Boehringer Ingelheim, Novartis, Tesaro, Takeda, Vifor Pharma, AbbVie, outside the submitted work. M Provencio has received honoraria from Roche, Eli Lilly, Boehringer Ingelheim, AstraZeneca, and Bristol-Myers Squibb, outside the submitted work. The rest of the authors declare that they have not conflicts of interest.

Ethical statement The study has been performed in accordance with the ethical standards of the Declaration of Helsinki and its later amendments. This article does not contain any studies with human participants or animals performed by any of the authors.

Informed consent For this type of study formal consent is not required.
Open Access This article is distributed under the terms of the Creative Commons Attribution 4.0 International License (http://creativeco mmons.org/licenses/by/4.0/), which permits unrestricted use, distribution, and reproduction in any medium, provided you give appropriate credit to the original author(s) and the source, provide a link to the Creative Commons license, and indicate if changes were made.

\section{References}

1. Rami-Porta R, Bolejack V, Crowley J, Ball D, Kim J, Lyons G. The IASLC lung cancer staging project: proposals for the revisions of the $\mathrm{T}$ descriptors in the forthcoming eighth edition of the TNM classification for lung cancer. J Thorac Oncol. 2015; 10:990-1003.

2. Rami-Porta R, Call S, Dooms C, Obiols C, Sanchez M, Travis WD, et al. Lung cancer staging: a concise update. Eur Respir J. 2018;51(5):1800190.

3. Goldstraw P, Chansky K, Crowley J, Rami-Porta R, Asamura $\mathrm{H}$, Eberhardt WE, et al. The IASLC lung cancer staging project: proposals for revision of the TNM stage groupings in the forthcoming (eighth) edition of the TNM classification for lung cancer. J Thorac Oncol. 2016;11:39-51.

4. Kirsch J, Ramirez J, Mohammed TL, Amorosa JK, Brown K, Dyer DS, et al. ACR Appropriateness Criteria(R) acute respiratory illness in immunocompetent patients. J Thorac Imaging. 2011;26:W42-4.

5. de Castro J, Cobo M, Isla D, Puente J, Reguart N, Cabeza B, et al. Recommendations for radiological diagnosis and assessment of treatment response in lung cancer: a national consensus statement by the Spanish Society of Medical Radiology and the Spanish Society of Medical Oncology. Clin Transl Oncol. 2015; $17: 11-23$.

6. Gross BH, Brown RK, Kalemkerian GP. Optimal anatomic coverage for CT in staging lung cancer: lessons from PET-CT correlation. Lung Cancer. 2011;73:59-62.

7. Kajiwara N, Akata S, Uchida O, Usuda J, Ohira T, Kawate N, et al. Cine MRI enables better therapeutic planning than CT in cases of possible lung cancer chest wall invasion. Lung Cancer. 2010;69:203-8.

8. Bandi V, Lunn W, Ernst A, Eberhardt R, Hoffmann H, Herth FJ. Ultrasound vs. CT in detecting chest wall invasion by tumor: a prospective study. Chest. 2008;133:881-6.

9. Bruzzi JF, Komaki R, Walsh GL, Truong MT, Gladish GW, Munden RF, et al. Imaging of non-small cell lung cancer of the superior sulcus: part 2: initial staging and assessment of resectability and therapeutic response. Radiographics. 2008;28:561-72.

10. Gelberg J, Grondin S, Tremblay A. Mediastinal staging for lung cancer. Can Respir J. 2014;21:159-61.

11. Gould MK, Kuschner WG, Rydzak CE, Maclean CC, Demas AN, Shigemitsu H, et al. Test performance of positron emission tomography and computed tomography for mediastinal staging in patients with non-small-cell lung cancer: a meta-analysis. Ann Intern Med. 2003;139:879-92.

12. Prenzel KL, Monig SP, Sinning JM, Baldus SE, Brochhagen HG, Schneider PM, et al. Lymph node size and metastatic infiltration in non-small cell lung cancer. Chest. 2003;123:463-7.

13. Shim SS, Lee KS, Kim BT, Chung MJ, Lee EJ, Han J, et al. Non-small cell lung cancer: prospective comparison of integrated FDG PET/CT and CT alone for preoperative staging. Radiology. 2005;236:1011-9.

14. Zhao L, He ZY, Zhong XN, Cui ML. (18)FDG-PET/CT for detection of mediastinal nodal metastasis in non-small cell lung cancer: a meta-analysis. Surg Oncol. 2012;21:230-6. 
15. Lv YL, Yuan DM, Wang K, Miao XH, Qian Q, Wei SZ, et al. Diagnostic performance of integrated positron emission tomography/computed tomography for mediastinal lymph node staging in non-small cell lung cancer: a bivariate systematic review and meta-analysis. J Thorac Oncol. 2011;6:1350-8.

16. Stigt JA, Boers JE, Boomsma MF. Ultrasound-guided tissue core biopsies in supraclavicular lymph nodes in patients with suspected thoracic malignancies. Respiration. 2015;90:412-5.

17. Hernández Hernández JR, Cordovilla-Pérez R, Novoa-Valentín NM, Gómez-Hernández MT, Sánchez de Cos Escuín J. Carcinoma broncogénico: diagnóstico y estadificación. Manual de la Sociedad Española de Neumología y Cirugía Torácica (SEPAR). vol Capítulo 67. 2018. https://www.separ.es. Accessed 10 Dec 2018.

18. Harders SW, Balyasnikowa S, Fischer BM. Functional imaging in lung cancer. Clin Physiol Funct Imaging. 2014;34:340-55.

19. Postmus PE, Kerr KM, Oudkerk M, Senan S, Waller DA, Vansteenkiste J, et al. Early and locally advanced non-small-cell lung cancer (NSCLC): ESMO clinical practice guidelines for diagnosis, treatment and follow-up. Ann Oncol. 2017;28:1-21.

20. Millon D, Byl D, Collard P, Cambier SE, Van Maanen AG, Vlassenbroek A, et al. Could new reconstruction CT techniques challenge MRI for the detection of brain metastases in the context of initial lung cancer staging? Eur Radiol. 2018;28:770-9.

21. Lee HY, Lee KS, Kim BT, Cho YS, Lee EJ, Yi CA, et al. Diagnostic efficacy of PET/CT plus brain MR imaging for detection of extrathoracic metastases in patients with lung adenocarcinoma. J Korean Med Sci. 2009;24:1132-8.

22. Silvestri GA, Gonzalez AV, Jantz MA, Margolis ML, Gould MK, Tanoue LT, et al. Methods for staging non-small cell lung cancer: diagnosis and management of lung cancer, 3rd ed: American College of Chest Physicians evidence-based clinical practice guidelines. Chest. 2013;143:e211S-50S.

23. Ettinger DS, Wood DE, Aisner DL, Akerley W, Bauman J, Chang JY. Non-Small Cell Lung Cancer, Version 5.2018, NCCN clinical practice guidelines in oncology. 2018. https ://www.nccn.org/professionals/physician_gls/pdf/nscl.pdf. Accessed 10 Dec 2018.

24. Murgu SD. Diagnosing and staging lung cancer involving the mediastinum. Chest. 2015;147:1401-12.

25. Vilmann P, Clementsen PF, Colella S, Siemsen M, De Leyn P, Dumonceau JM, et al. Combined endobronchial and oesophageal endosonography for the diagnosis and staging of lung cancer. European Society of Gastrointestinal Endoscopy (ESGE) guideline, in cooperation with the European Respiratory Society (ERS) and the European Society of Thoracic Surgeons (ESTS). Eur Respir J. 2015;46:40-60.

26. De Leyn P, Dooms C, Kuzdzal J, Lardinois D, Passlick B, Rami-Porta R, et al. Revised ESTS guidelines for preoperative mediastinal lymph node staging for non-small-cell lung cancer. Eur J Cardiothorac Surg. 2014;45:787-98.

27. Decaluwe H, Dooms C, D'Journo XB, Call S, Sanchez D, Haager B, et al. Mediastinal staging by videomediastinoscopy in clinical N1 non-small cell lung cancer: a prospective multicentre study. Eur Respir J. 2017;50(6): 1701493.

28. Gao SJ, Kim AW, Puchalski JT, Bramley K, Detterbeck FC, Boffa DJ, et al. Indications for invasive mediastinal staging in patients with early non-small cell lung cancer staged with PET-CT. Lung Cancer. 2017;109:36-41.

29. Hammoud ZT, Anderson RC, Meyers BF, Guthrie TJ, Roper CL, Cooper JD, et al. The current role of mediastinoscopy in the evaluation of thoracic disease. J Thorac Cardiovasc Surg. 1999;118:894-9.

30. Deslauriers J, Beaulieu M, Dufour C, Michaud P, Despres JP, Lemieux M. Mediastinopleuroscopy: a new approach to the diagnosis of intrathoracic diseases. Ann Thorac Surg. 1976;22:265-9.

31. Trujillo-Reyes JC, Martinez-Tellez E, Rami-Porta R, Obiols C, Call S, Belda-Sanchis J. Combination video-assisted mediastinoscopic lymphadenectomy and transcervical thoracoscopy. Multimed Man Cardiothorac Surg. 2018. https://doi. org/10.1510/mmcts.2018.004

32. Loscertales J, Jimenez-Merchan R, Congregado M, Ayarra FJ, Gallardo G, Trivino A. Video-assisted surgery for lung cancer. State of the art and personal experience. Asian Cardiovasc Thorac Ann. 2009;17:313-26.

33. Tanvetyanon T, Eikman EA, Sommers E, Robinson L, Boulware D, Bepler G. Computed tomography response, but not positron emission tomography scan response, predicts survival after neoadjuvant chemotherapy for resectable non-small-cell lung cancer. J Clin Oncol. 2008;26:4610-6.

34. Milleron B, Westeel V, Quoix E, Moro-Sibilot D, Braun D, Lebeau B, et al. Complete response following preoperative chemotherapy for resectable non-small cell lung cancer: accuracy of clinical assessment using the French trial database. Chest. 2005;128:1442-7.

35. Cerfolio RJ, Bryant AS. When is it best to repeat a 2-fluoro2-deoxy-D-glucose positron emission tomography/computed tomography scan on patients with non-small cell lung cancer who have received neoadjuvant chemoradiotherapy? Ann Thorac Surg. 2007;84:1092-7.

36. Dooms C, Verbeken E, Stroobants S, Nackaerts K, De Leyn P, Vansteenkiste J. Prognostic stratification of stage IIIA-N2 non-small-cell lung cancer after induction chemotherapy: a model based on the combination of morphometric-pathologic response in mediastinal nodes and primary tumor response on serial 18-fluoro-2-deoxy-glucose positron emission tomography. J Clin Oncol. 2008;26:1128-34.

37. Eschmann SM, Friedel G, Paulsen F, Reimold M, Hehr T, Budach W, et al. 18F-FDG PET for assessment of therapy response and preoperative re-evaluation after neoadjuvant radio-chemotherapy in stage III non-small cell lung cancer. Eur J Nucl Med Mol Imaging. 2007;34:463-71.

38. Lardinois D, Weder W, Hany TF, Kamel EM, Korom S, Seifert $\mathrm{B}$, et al. Staging of non-small-cell lung cancer with integrated positron-emission tomography and computed tomography. $\mathrm{N}$ Engl J Med. 2003;348:2500-7.

39. Kunst PW, Lee P, Paul MA, Senan S, Smit EF. Restaging of mediastinal nodes with transbronchial needle aspiration after induction chemoradiation for locally advanced non-small cell lung cancer. J Thorac Oncol. 2007;2:912-5.

40. Herth FJ, Annema JT, Eberhardt R, Yasufuku K, Ernst A, Krasnik M, et al. Endobronchial ultrasound with transbronchial needle aspiration for restaging the mediastinum in lung cancer. $\mathbf{J}$ Clin Oncol. 2008;26:3346-50.

41. Szlubowski A, Herth FJ, Soja J, Kolodziej M, Figura J, Cmiel A, et al. Endobronchial ultrasound-guided needle aspiration in non-small-cell lung cancer restaging verified by the transcervical bilateral extended mediastinal lymphadenectomy-a prospective study. Eur J Cardiothorac Surg. 2010;37:1180-4.

42. Zielinski M, Szlubowski A, Kolodziej M, Orzechowski S, Laczynska E, Pankowski J, et al. Comparison of endobronchial ultrasound and/or endoesophageal ultrasound with transcervical extended mediastinal lymphadenectomy for staging and restaging of non-small-cell lung cancer. J Thorac Oncol. 2013;8:630-6.

43. Szlubowski A, Zielinski M, Soja J, Filarecka A, Orzechowski S, Pankowski J, et al. Accurate and safe mediastinal restaging by combined endobronchial and endoscopic ultrasound-guided needle aspiration performed by single ultrasound bronchoscope. Eur J Cardiothorac Surg. 2014;46:262-6. 
44. Zielinski M, Hauer L, Hauer J, Nabialek T, Szlubowski A, Pankowski J. Non-small-cell lung cancer restaging with transcervical extended mediastinal lymphadenectomy. Eur J Cardiothorac Surg. 2010;37:776-80.

45. Rami-Porta R, Call S. Invasive staging of mediastinal lymph nodes: mediastinoscopy and remediastinoscopy. Thorac Surg Clin. 2012;22:177-89.

46. De Waele M, Serra-Mitjans M, Hendriks J, Lauwers P, BeldaSanchis J, Van Schil P, et al. Accuracy and survival of repeat mediastinoscopy after induction therapy for non-small cell lung cancer in a combined series of 104 patients. Eur J Cardiothorac Surg. 2008;33:824-8.

47. Marra A, Hillejan L, Fechner S, Stamatis G. Remediastinoscopy in restaging of lung cancer after induction therapy. J Thorac Cardiovasc Surg. 2008;135:843-9.

48. Stamatis G, Fechner S, Hillejan L, Hinterthaner M, Krbek T. Repeat mediastinoscopy as a restaging procedure. Pneumologie. 2005;59:862-6.

49. Kuzdzal J, Zielinski M, Papla B, Szlubowski A, Hauer L, Nabialek $\mathrm{T}$, et al. Transcervical extended mediastinal lymphadenectomy-the new operative technique and early results in lung cancer staging. Eur J Cardiothorac Surg. 2005;27:384-90 (discussion 90)

50. Jaklitsch MT, Gu L, Demmy T, Harpole DH, D'Amico TA, McKenna RJ, et al. Prospective phase II trial of preresection thoracoscopic mediastinal restaging after neoadjuvant therapy for IIIA (N2) non-small cell lung cancer: results of CALGB Protocol 39803. J Thorac Cardiovasc Surg. 2013;146:9-16.

51. Brunelli A, Kim AW, Berger KI, Addrizzo-Harris DJ. Physiologic evaluation of the patient with lung cancer being considered for resectional surgery: diagnosis and management of lung cancer, 3rd ed: American College of Chest Physicians evidencebased clinical practice guidelines. Chest. 2013;143:e166S-90S.

52. Lim E, Baldwin D, Beckles M, Duffy J, Entwisle J, Faivre-Finn $\mathrm{C}$, et al. Guidelines on the radical management of patients with lung cancer. Thorax. 2010;65(Suppl 3):1-27.

53. Sawabata N, Nagayasu T, Kadota Y, Goto T, Horio H, Mori T, et al. Risk assessment of lung resection for lung cancer according to pulmonary function: republication of systematic review and proposals by guideline committee of the Japanese association for chest surgery 2014. Gen Thorac Cardiovasc Surg. 2015;63:14-21.

54. Dehing-Oberije C, De Ruysscher D, van Baardwijk A, Yu S, Rao B, Lambin P. The importance of patient characteristics for the prediction of radiation-induced lung toxicity. Radiother Oncol. 2009;91:421-6.

55. Douillard JY, Rosell R, De Lena M, Carpagnano F, Ramlau R, Gonzales-Larriba JL, et al. Adjuvant vinorelbine plus cisplatin versus observation in patients with completely resected stage IB-IIIA non-small-cell lung cancer (Adjuvant Navelbine International Trialist Association [ANITA]): a randomised controlled trial. Lancet Oncol. 2006;7:719-27.

56. Pignon JP, Tribodet H, Scagliotti GV, Douillard JY, Shepherd FA, Stephens RJ, et al. Lung adjuvant cisplatin evaluation: a pooled analysis by the LACE Collaborative Group. J Clin Oncol. 2008;26:3552-9.

57. Okawara G, Ung YC, Markman BR, Mackay JA, Evans WK, Group TL, PORT Meta-analysis Trialists Group. Postoperative radiotherapy in non-small-cell lung cancer: systematic review and meta-analysis of individual patient data from nine randomised controlled trials. Lancet. 1998;352:257-63.

58. Burdett S, Rydzewska L, Tierney J, Fisher D, Parmar MK, Arriagada $\mathrm{R}$ et al. Postoperative radiotherapy for non-small cell lung cancer. Cochrane Database Syst Rev. 2016;9:CD002142.
59. Burdett S, Stewart L, Group PM-a. Postoperative radiotherapy in non-small-cell lung cancer: update of an individual patient data meta-analysis. Lung Cancer. 2005;47:81-3.

60. Gomez A, Gonzalez JA, Counago F, Vallejo C, Casas F, de Dios NR. Evidence-based recommendations of postoperative radiotherapy in lung cancer from Oncologic Group for the Study of Lung Cancer (Spanish Radiation Oncology Society). Clin Transl Oncol. 2016;18:331-41.

61. Lally BE, Zelterman D, Colasanto JM, Haffty BG, Detterbeck FC, Wilson LD. Postoperative radiotherapy for stage II or III non-small-cell lung cancer using the surveillance, epidemiology, and end results database. J Clin Oncol. 2006;24:2998-3006.

62. Robinson CG, Patel AP, Bradley JD, DeWees T, Waqar SN, Morgensztern D, et al. Postoperative radiotherapy for pathologic $\mathrm{N} 2$ non-small-cell lung cancer treated with adjuvant chemotherapy: a review of the National Cancer Data Base. J Clin Oncol. 2015;33:870-6.

63. Billiet C, Decaluwe H, Peeters S, Vansteenkiste J, Dooms C, Haustermans K, et al. Modern post-operative radiotherapy for stage III non-small cell lung cancer may improve local control and survival: a meta-analysis. Radiother Oncol. 2014;110:3-8.

64. Burdett S, Stewart LA, Rydzewska L. A systematic review and meta-analysis of the literature: chemotherapy and surgery versus surgery alone in non-small cell lung cancer. J Thorac Oncol. 2006;1:611-21.

65. Nagai K, Tsuchiya R, Mori T, Tada H, Ichinose Y, Koike T, et al. A randomized trial comparing induction chemotherapy followed by surgery with surgery alone for patients with stage IIIA N2 non-small cell lung cancer (JCOG 9209). J Thorac Cardiovasc Surg. 2003;125:254-60.

66. Rosell R, Gomez-Codina J, Camps C, Sanchez JJ, Maestre J, Padilla J, et al. Preresectional chemotherapy in stage IIIA nonsmall-cell lung cancer: a 7-year assessment of a randomized controlled trial. Lung Cancer. 1999;26:7-14.

67. Rosell R, Gomez-Codina J, Camps C, Maestre J, Padille J, Canto $\mathrm{A}$, et al. A randomized trial comparing preoperative chemotherapy plus surgery with surgery alone in patients with non-smallcell lung cancer. N Engl J Med. 1994;330:153-8.

68. Roth JA, Atkinson EN, Fossella F, Komaki R, Bernadette Ryan M, Putnam JB Jr, et al. Long-term follow-up of patients enrolled in a randomized trial comparing perioperative chemotherapy and surgery with surgery alone in resectable stage IIIA non-small-cell lung cancer. Lung Cancer. 1998;21:1-6.

69. Roth JA, Fossella F, Komaki R, Ryan MB, Putnam JB Jr, Lee $\mathrm{JS}$, et al. A randomized trial comparing perioperative chemotherapy and surgery with surgery alone in resectable stage IIIA non-small-cell lung cancer. J Natl Cancer Inst. 1994;86:673-80.

70. Song WA, Zhou NK, Wang W, Chu XY, Liang CY, Tian XD, et al. Survival benefit of neoadjuvant chemotherapy in non-small cell lung cancer: an updated meta-analysis of 13 randomized control trials. J Thorac Oncol. 2010;5:510-6.

71. Varlotto JM, Yao AN, DeCamp MM, Ramakrishna S, Recht A, Flickinger J, et al. Nodal stage of surgically resected non-small cell lung cancer and its effect on recurrence patterns and overall survival. Int J Radiat Oncol Biol Phys. 2015;91:765-73.

72. Andre F, Grunenwald D, Pignon JP, Dujon A, Pujol JL, Brichon PY, et al. Survival of patients with resected N2 non-small-cell lung cancer: evidence for a subclassification and implications. $\mathbf{J}$ Clin Oncol. 2000;18:2981-9.

73. Group NM-aC. Preoperative chemotherapy for non-small-cell lung cancer: a systematic review and meta-analysis of individual participant data. Lancet. 2014;383:1561-71.

74. Albain KS, Swann RS, Rusch VW, Turrisi AT 3rd, Shepherd FA, Smith C, et al. Radiotherapy plus chemotherapy with or without 
surgical resection for stage III non-small-cell lung cancer: a phase III randomised controlled trial. Lancet. 2009;374:379-86.

75. van Meerbeeck JP, Kramer GW, Van Schil PE, Legrand C, Smit EF, Schramel F, et al. Randomized controlled trial of resection versus radiotherapy after induction chemotherapy in stage IIIA-N2 non-small-cell lung cancer. J Natl Cancer Inst. 2007;99:442-50.

76. Counago F, de Dios NR, Montemuino S, Jove-Teixido J, Martin M, Calvo-Crespo P, et al. Neoadjuvant treatment followed by surgery versus definitive chemoradiation in stage IIIA-N2 non-small-cell lung cancer: a multi-institutional study by the oncologic group for the study of lung cancer (Spanish Radiation Oncology Society). Lung Cancer. 2018;118:119-27.

77. Thomas M, Rube C, Hoffknecht P, Macha HN, Freitag L, Linder A, et al. Effect of preoperative chemoradiation in addition to preoperative chemotherapy: a randomised trial in stage III nonsmall-cell lung cancer. Lancet Oncol. 2008;9:636-48.

78. Shah AA, Berry MF, Tzao C, Gandhi M, Worni M, Pietrobon $\mathrm{R}$, et al. Induction chemoradiation is not superior to induction chemotherapy alone in stage IIIA lung cancer. Ann Thorac Surg. 2012;93:1807-12.

79. Chen Y, Peng X, Zhou Y, Xia K, Zhuang W. Comparing the benefits of chemoradiotherapy and chemotherapy for resectable stage III A/N2 non-small cell lung cancer: a meta-analysis. World J Surg Oncol. 2018;16:8.

80. Rami-Porta R, Wittekind C, Goldstraw P, International Association for the Study of Lung Cancer Staging C. Complete resection in lung cancer surgery: proposed definition. Lung Cancer. 2005;49:25-33.

81. Detterbeck FC, Lewis SZ, Diekemper R, Addrizzo-Harris D, Alberts WM. Executive Summary: diagnosis and management of lung cancer, 3rd ed: American College of Chest Physicians evidence-based clinical practice guidelines. Chest. 2013;143:7S-37S.

82. Eberhardt WE, De Ruysscher D, Weder W, Le Pechoux C, De Leyn P, Hoffmann H, et al. 2nd ESMO consensus conference in lung cancer: locally advanced stage III non-small-cell lung cancer. Ann Oncol. 2015;26:1573-88.

83. Rocco G, Nason K, Brunelli A, Varela G, Waddell T, Jones DR. Management of Stage IIIA (N2) non-small cell lung cancer: a transatlantic perspective. Ann Thorac Surg. 2016;101:1247-50.

84. De Leyn P, Lardinois D, Van Schil PE, Rami-Porta R, Passlick B, Zielinski M, et al. ESTS guidelines for preoperative lymph node staging for non-small cell lung cancer. Eur J Cardiothorac Surg. 2007;32:1-8.

85. Hudson J, Semenkovich T, Puri V. Oncologic Quality Indicators in Thoracic Surgery. Thorac Surg Clin. 2017;27:227-44.

86. Watanabe SI, Nakagawa K, Suzuki K, Takamochi K, Ito H, Okami J, et al. Neoadjuvant and adjuvant therapy for Stage III non-small cell lung cancer. Jpn J Clin Oncol. 2017;47:1112-8.

87. Arriagada R, Dunant A, Pignon JP, Bergman B, Chabowski M, Grunenwald D, et al. Long-term results of the international adjuvant lung cancer trial evaluating adjuvant Cisplatin-based chemotherapy in resected lung cancer. J Clin Oncol. 2010;28:35-42.

88. Douillard JY, Rosell R, De Lena M, Riggi M, Hurteloup P, Mahe MA, et al. Impact of postoperative radiation therapy on survival in patients with complete resection and stage I, II, or IIIA non-small-cell lung cancer treated with adjuvant chemotherapy: the adjuvant Navelbine International Trialist Association (ANITA) Randomized Trial. Int J Radiat Oncol Biol Phys. 2008;72:695-701.

89. Auperin A, Le Pechoux C, Rolland E, Curran WJ, Furuse K, Fournel P, et al. Meta-analysis of concomitant versus sequential radiochemotherapy in locally advanced non-small-cell lung cancer. J Clin Oncol. 2010;28:2181-90.
90. Krzakowski M, Provencio M, Utracka-Hutka B, Villa E, Codes $\mathrm{M}$, Kuten A, et al. Oral vinorelbine and cisplatin as induction chemotherapy and concomitant chemo-radiotherapy in stage III non-small cell lung cancer: final results of an international phase II trial. J Thorac Oncol. 2008;3:994-1002.

91. Bradley JD, Paulus R, Komaki R, Masters G, Blumenschein G, Schild S, et al. Standard-dose versus high-dose conformal radiotherapy with concurrent and consolidation carboplatin plus paclitaxel with or without cetuximab for patients with stage IIIA or IIIB non-small-cell lung cancer (RTOG 0617): a randomised, two-bytwo factorial phase 3 study. Lancet Oncol. 2015;16:187-99.

92. Hanna N, Neubauer M, Yiannoutsos C, McGarry R, Arseneau J, Ansari R, et al. Phase III study of cisplatin, etoposide, and concurrent chest radiation with or without consolidation docetaxel in patients with inoperable stage III non-small-cell lung cancer: the Hoosier Oncology Group and U.S. Oncology. J Clin Oncol. 2008;26:5755-60.

93. Ahn JS, Ahn YC, Kim JH, Lee CG, Cho EK, Lee KC, et al. Multinational randomized phase III trial with or without consolidation chemotherapy using docetaxel and cisplatin after concurrent chemoradiation in inoperable stage III non-small-cell lung cancer: KCSG-LU05-04. J Clin Oncol. 2015;33:2660-6.

94. Curran WJ, Paulus R, Langer CJ, Komaki R, Lee JS, Hauser S, et al. Sequential vs concurrent chemoradiation for stage III nonsmall cell lung cancer: randomized phase III trial RTOG 9410. J Natl Cancer Inst. 2011;103:1452-60.

95. Vokes EE, Herndon JE 2nd, Kelley MJ, Cicchetti MG, Ramnath $\mathrm{N}$, Neill $\mathrm{H}$, et al. Induction chemotherapy followed by chemoradiotherapy compared with chemoradiotherapy alone for regionally advanced unresectable stage III Non-small-cell lung cancer: cancer and Leukemia Group B. J Clin Oncol. 2007;25:1698-704.

96. Senan S, Brade A, Wang LH, Vansteenkiste J, Dakhil S, Biesma B, et al. PROCLAIM: randomized phase III trial of pemetrexedcisplatin or etoposide-cisplatin plus thoracic radiation therapy followed by consolidation chemotherapy in locally advanced nonsquamous non-small-cell lung cancer. J Clin Oncol. 2016;34:953-62.

97. De Ruysscher D, Faivre-Finn C, Moeller D, Nestle U, Hurkmans $\mathrm{CW}$, Le Pechoux C, et al. European Organization for Research and Treatment of Cancer (EORTC) recommendations for planning and delivery of high-dose, high precision radiotherapy for lung cancer. Radiother Oncol. 2017;124:1-10.

98. De Ruysscher D, Wanders S, van Haren E, Hochstenbag M, Geeraedts W, Utama I, et al. Selective mediastinal node irradiation based on FDG-PET scan data in patients with non-small-cell lung cancer: a prospective clinical study. Int J Radiat Oncol Biol Phys. 2005;62:988-94.

99. Yuan S, Sun X, Li M, Yu J, Ren R, Yu Y, et al. A randomized study of involved-field irradiation versus elective nodal irradiation in combination with concurrent chemotherapy for inoperable stage III nonsmall cell lung cancer. Am J Clin Oncol. 2007;30:239-44.

100. Billiet C, De Ruysscher D, Peeters S, Decaluwe H, Vansteenkiste J, Dooms C, et al. Patterns of locoregional relapses in patients with contemporarily staged stage III-N2 NSCLC treated with induction chemotherapy and resection: implications for postoperative radiotherapy target volumes. J Thorac Oncol. 2016;11:1538-49.

101. Marks LB, Bentzen SM, Deasy JO, Kong FM, Bradley JD, Vogelius IS, et al. Radiation dose-volume effects in the lung. Int $\mathrm{J}$ Radiat Oncol Biol Phys. 2010;76:S70-6.

102. Stam B, van der Bijl E, van Diessen J, Rossi MMG, Tijhuis A, Belderbos JSA, et al. Heart dose associated with overall survival in locally advanced NSCLC patients treated with hypofractionated chemoradiotherapy. Radiother Oncol. 2017;125:62-5.

103. Foundation R. Atlases for CT Gross Tumor Volume (CTGTV) and PET Metabolic Tumor Volume (PETMTV) for RTOG 1106. 
2. https://www.rtog.org/CoreLab/ContouringAtlases/LungAtlas. aspx. Accessed 14 Nov 2018.

104. Keall PJ, Mageras GS, Balter JM, Emery RS, Forster KM, Jiang SB, et al. The management of respiratory motion in radiation oncology report of AAPM Task Group 76. Med Phys. 2006;33:3874-900.

105. Mauguen A, Le Pechoux C, Saunders MI, Schild SE, Turrisi AT, Baumann M, et al. Hyperfractionated or accelerated radiotherapy in lung cancer: an individual patient data meta-analysis. J Clin Oncol. 2012;30:2788-97.

106. Cerfolio RJ, Bryant AS, Jones VL, Cerfolio RM. Pulmonary resection after concurrent chemotherapy and high dose $(60 \mathrm{~Gy})$ radiation for non-small cell lung cancer is safe and may provide increased survival. Eur J Cardiothorac Surg. 2009;35:718-23 (discussion 23).

107. Sher DJ, Fidler MJ, Seder CW, Liptay MJ, Koshy M. Relationship between radiation therapy dose and outcome in patients treated with neoadjuvant chemoradiation therapy and surgery for stage IIIA non-small cell lung cancer: a population-based, comparative effectiveness analysis. Int J Radiat Oncol Biol Phys. 2015;92:307-16.

108. Excellence NIfHaC. Lung cancer: diagnosis and managementLung cancer: diagnosis and management. 2011. https://www.nice.org.uk/ guidance/cg121/resources/lung-cancer-diagnosis-and-management -pdf-35109444863941. Accessed Oct 2018.

109. Network NCC. NCCN Non-Small Cell Lung Cancer V.9.2017follow-up-September 20, 2017. 2017. https://www.nccn.org/profe ssionals/physician_gls/default.aspx. Accessed Oct 2018.

110. Ray M, Faris N, Rugless F, Smeltzer M, Foust C, Jackson B, et al. Multidisciplinary care and the use of treatment modalities for nonsmall cell lung cancer (NSCLC) in a large community healthcare setting. Int J Radiat Oncol Biol Phys. 2017;98:226.

111. Alvarez FV, Trueba IM, Sanchis JB, Lopez-Rodo LM, Suarez PM, de Cos Escuin JS, et al. Executive summary of the SEPAR recommendations for the diagnosis and treatment of non-small cell lung cancer. Arch Bronconeumol. 2016;52:378-88.

112. Brunelli A, Charloux A, Bolliger CT, Rocco G, Sculier JP, Varela G, et al. ERS/ESTS clinical guidelines on fitness for radical therapy in lung cancer patients (surgery and chemo-radiotherapy). Eur Respir J. 2009;34:17-41.

113. Harris C, Meek D, Gilligan D, Williams L, Solli P, Rintoul RC. Assessment and optimisation of lung cancer patients for treatment with curative intent. Clin Oncol (R Coll Radiol). 2016;28:682-94.

114. Donington JS, Kim YT, Tong B, Moreira AL, Bessich J, Weiss KD, et al. Progress in the management of early-stage non-small cell lung cancer in 2017. J Thorac Oncol. 2018;13:767-78.

115. Massard G, Renaud S, Reeb J, Santelmo N, Olland A, Falcoz PE. N2-IIIA non-small cell lung cancer: a plea for surgery! J Thorac Dis. 2016;8:S849-54.

116. Dinic VD, Stojanovic MD, Markovic D, Cvetanovic V, Vukovic AZ, Jankovic RJ. Enhanced recovery in thoracic surgery: a review. Front Med (Lausanne). 2018;5:14.

117. Jalal SI, Riggs HD, Melnyk A, Richards D, Agarwala A, Neubauer $\mathrm{M}$, et al. Updated survival and outcomes for older adults with inoperable stage III non-small-cell lung cancer treated with cisplatin, etoposide, and concurrent chest radiation with or without consolidation docetaxel: analysis of a phase III trial from the Hoosier Oncology Group (HOG) and US Oncology. Ann Oncol. 2012;23:1730-8.

118. Giaccone G, Bazhenova LA, Nemunaitis J, Tan M, Juhasz E, Ramlau R, et al. A phase III study of belagenpumatucel-L, an allogeneic tumour cell vaccine, as maintenance therapy for non-small cell lung cancer. Eur J Cancer. 2015;51:2321-9.

119. Tsujino K, Kurata T, Yamamoto S, Kawaguchi T, Kubo A, Isa S, et al. Is consolidation chemotherapy after concurrent chemo-radiotherapy beneficial for patients with locally advanced non-small-cell lung cancer? A pooled analysis of the literature. J Thorac Oncol. 2013;8:1181-9.
120. Antonia SJ, Villegas A, Daniel D, Vicente D, Murakami S, Hui R, et al. Overall survival with durvalumab after chemoradiotherapy in stage III NSCLC. N Engl J Med. 2018;379(24):2342-50.

121. Warren GW, Ward KD. Integration of tobacco cessation services into multidisciplinary lung cancer care: rationale, state of the art, and future directions. Transl Lung Cancer Res. 2015;4:339-52.

122. Ferreiros J, Cabeza B, Gayete A, Sanchez M, Torres MI, Cobo M, et al. [Recommendations for radiological diagnosis and assessment of treatment response in lung cancer: a national consensus statement by the Spanish Society of Medical Radiology and the Spanish Society of Medical Oncology]. Radiologia. 2015;57:66-78.

123. Dane B, Grechushkin V, Plank A, Moore W, Bilfinger T. PET/CT vs. non-contrast CT alone for surveillance 1-year post lobectomy for stage I non-small-cell lung cancer. Am J Nucl Med Mol Imaging. 2013;3:408-16.

124. Calais J, Thureau S, Dubray B, Modzelewski R, Thiberville L, Gardin I, et al. Areas of high 18F-FDG uptake on preradiotherapy PET/ CT identify preferential sites of local relapse after chemoradiotherapy for non-small cell lung cancer. J Nucl Med. 2015;56:196-203.

125. Aukema TS, Kappers I, Olmos RA, Codrington HE, van Tinteren $\mathrm{H}$, van Pel R, et al. Is 18F-FDG PET/CT useful for the early prediction of histopathologic response to neoadjuvant erlotinib in patients with non-small cell lung cancer? J Nucl Med. 2010;51:1344-8.

126. Pottgen C, Levegrun S, Theegarten D, Marnitz S, Grehl S, Pink $\mathrm{R}$, et al. Value of 18F-fluoro-2-deoxy-D-glucose-positron emission tomography/computed tomography in non-small-cell lung cancer for prediction of pathologic response and times to relapse after neoadjuvant chemoradiotherapy. Clin Cancer Res. 2006;12:97-106.

127. Sunaga N, Oriuchi N, Kaira K, Yanagitani N, Tomizawa Y, Hisada T, et al. Usefulness of FDG-PET for early prediction of the response to gefitinib in non-small cell lung cancer. Lung Cancer. 2008;59:203-10.

128. Eisenhauer EA, Therasse P, Bogaerts J, Schwartz LH, Sargent D, Ford R, et al. New response evaluation criteria in solid tumours: revised RECIST guideline (version 11). Eur J Cancer. 2009;45:228-47.

129. Seymour L, Bogaerts J, Perrone A, Ford R, Schwartz LH, Mandrekar S, et al. iRECIST: guidelines for response criteria for use in trials testing immunotherapeutics. Lancet Oncol. 2017;18:e143-52.

130. Lemaire A, Nikolic I, Petersen T, Haney JC, Toloza EM, Harpole $\mathrm{DH}$, et al. Nine-year single center experience with cervical mediastinoscopy: complications and false negative rate. Ann Thorac Surg. 2006;82:1185-9 (discussion 9-90).

131. Obiols C, Call S, Rami-Porta R, Iglesias M, Saumench R, SerraMitjans M, et al. Extended cervical mediastinoscopy: mature results of a clinical protocol for staging bronchogenic carcinoma of the left lung. Eur J Cardiothorac Surg. 2012;41:1043-6.

132. Page A, Nakhle G, Mercier C, Verdant A, Page P, Dontigny L, et al. Surgical treatment of bronchogenic carcinoma: the importance of staging in evaluating late survival. Can J Surg. 1987;30:96-9.

133. Massone PP, Lequaglie C, Magnani B, Ferro F, Cataldo I. The real impact and usefulness of video-assisted thoracoscopic surgery in the diagnosis and therapy of clinical lymphadenopathies of the mediastinum. Ann Surg Oncol. 2003;10:1197-202.

134. Witte B, Wolf M, Huertgen M, Toomes H. Video-assisted mediastinoscopic surgery: clinical feasibility and accuracy of mediastinal lymph node staging. Ann Thorac Surg. 2006;82:1821-7.

135. Zielinski M, Hauer L, Hauer J, Pankowski J, Szlubowski A, Nabialek T. Transcervical extended mediastinal lymphadenectomy (TEMLA) for staging of non-small-cell lung cancer (NSCLC). Pneumonol Alergol Pol. 2011;79:196-206.

Publisher's Note Springer Nature remains neutral with regard to jurisdictional claims in published maps and institutional affiliations. 


\section{Affiliations}

M. Majem ${ }^{1}$ (1) - J. Hernández-Hernández ${ }^{2}$ - F. Hernando-Trancho ${ }^{3}$ - N. R. de Dios ${ }^{4} \cdot$ A. Sotoca $^{5} \cdot$ J. C. Trujillo-Reyes ${ }^{1}$. I. Vollmer ${ }^{6} \cdot$ R. Delgado-Bolton ${ }^{7} \cdot$ M. Provencio ${ }^{8}$

J. Hernández-Hernández

jhernandez@separ.es

F. Hernando-Trancho

fhtrancho@hotmail.com

N. Rodríguez de Dios nrodriguez@parcdesalutmar.cat

A. Sotoca

asotoca@ ruberinternacional.es

J. C. Trujillo-Reyes

JTrujillo@santpau.cat

I. Vollmer

vollmer@clinic.ub.es

R. Delgado-Bolton

rbiolton@gmail.com
M. Provencio

mprovencio.hpth@salud.madrid.org

1 Department of Medical Oncology, Hospital de la Santa Creu i Sant Pau, Sant Antoni María Claret, 167, 08025 Barcelona, Spain

2 Complejo Asistencial de Ávila, Ávila, Spain

3 Hospital Clínico San Carlos, Madrid, Spain

4 Hospital del Mar, Barcelona, Spain

5 Hospital Ruber Internacional, Madrid, Spain

6 Hospital Clínic, Barcelona, Spain

7 Hospital San Pedro, CIBIR, Logroño, Spain

8 Hospital Universitario Puerta de Hierro, Madrid, Spain 